\title{
All That Glitters Is Not Plumbate: Diffusion and Imitation of Plumbate Pottery during the Early Postclassic Period (AD 900-1200) at the Malpaís of Zacapu, Michoacán, Mexico
}

\author{
Elsa Jadot, Grégory Pereira, Hector Neff, and Michael D. Glascock
}

\begin{abstract}
In Mesoamerica, the Early Postclassic (AD 900-1200) is characterized by the long-distance circulation of pottery with a very hard and shiny coating with a metallic aspect, known as Plumbate ware. Plumbate is linked stylistically to the Toltec culture but was produced in workshops in Soconusco (Chiapas). The discovery of a similar collection of sherds during recent work at the site of El Palacio (Zacapu, Michoacán) shows that Plumbate ware also reached this region of Western Mexico. We carried out instrumental neutron activation analyses (INAA) on 11 of the Zacapu fragments and compared the results to the data from ceramic pastes from the region of Soconusco and Pátzcuaro Basin (Michoacán). Ten sherds were produced in Michoacán and are thus a local imitation, whereas the last fragment corresponds to a Tohil-type Plumbate paste and was transported over a long distance. This raises questions of the modalities for the circulation of this pot and the conditions allowing for production of an imitation (transfer of technical know-how?), which we suggest is linked to the Toltec culture in the center of Mexico.
\end{abstract}

Keywords: Mexico, Early Postclassic, Toltec, Plumbate ceramics, instrumental neutron activation analysis (INAA)

En México, durante el Posclásico temprano (900-1200 dC), se destaca la circulación a larga distancia de vasijas caracterizadas por un engobe de aspecto metálico muy duro y particularmente brilloso: la cerámica Plomiza. Se ha podido constatar la presencia en el centro-oeste de México de tiestos del auténtico tipo Plomizo Tohil, producción típica de la región maya de Soconusco (Chiapas), como así también la existencia de una imitación michoacana, a 1600 km de Chiapas. Durante las excavaciones arqueológicas en el sitio urbano El Palacio (Cuenca de Zacapu, Michoacán, México) se hallaron varios tiestos de aspecto similar a la cerámica Plomiza. Para comprobar la hipótesis de una imitación local o de una importación, se realizaron análisis por activación neutrónica (INAA) en 11 fragmentos. Los datos fueron comparados con los de las pastas cerámicas de la región de Soconusco y de la Cuenca de Pátzcuaro (Michoacán). Los resultados muestran que 10 tiestos fueron realizados en Michoacán y, en consecuencia, son una imitación local, mientras que un tiesto corresponde a la pasta del tipo Plomizo Tohil lo cual implica su circulación a larga distancia. Esto lleva a plantear cuestiones sobre las modalidades de circulación de esta cerámica y las condiciones que permitieron su imitación (¿transferencias de habilidades técnicas?), que sugerimos vincular con la cultura tolteca del centro de México.

Palabras clave: México, Posclásico temprano, tolteca, cerámica Plomiza, análisis por activación neutrónica (INAA)

$\mathrm{W}$ estern Mexico has long been considered to be on the fringe of the main Mesoamerican interaction systems, but the region is now perceived as a heterogeneous cultural complex with regular interactions with other regions of Mesoamerica, in particular with western Mexico, at different periods of its history. As early as the Preclassic period (Braniff

Elsa Jadot $\square$ Leiden University, Faculty of Archaeology, Einsteinweg 2, 2333 CC Leiden, Netherlands (elsa.j@sfr.fr, corresponding author)

Grégory Pereira - CNRS, UMR8096, 21 allée de l'Université, Nanterre, F-92023, France (gregory.pereira@cnrs.fr) Hector Neff $\square$ Department of Anthropology, California State University-Long Beach, 1250 Bellflower Blvd., Long Beach, CA 90840-1003, California USA (Hector.Neff@ csulb.edu)

Michael D. Glascock — Research Reactor Center, University of Missouri-Columbia, 1513 Research Park Drive, Columbia, MO 65211 Columbia, Missouri USA (GlascockM@missouri.edu)

Latin American Antiquity 30(2), 2019, pp. 318-332

Copyright $(\mathcal{C} 2019$ by the Society for American Archaeology. This is an Open Access article, distributed under the terms of the Creative Commons Attribution licence (http://creativecommons.org/licenses/by/4.0/), which permits unrestricted re-use, distribution, and reproduction in any medium, provided the original work is properly cited. 
1972; Carot 1992; Darras 2006) and then during the Classic period (Filini 2004; Filini and Cárdenas García 2007; Hernández 2016; Jiménez Betts 1992, 2018), the societies occupying this vast region established links with their neighbors to the east, as shown by an ever-increasing list of material markers. We also now know that the role of the West was not just a passive one and that Western Mexican products, symbols and even populations affected the historic trajectory of societies from central Mexico (Braniff 1972, 1999; Hers 2005; Manzanilla 2005). Michoacán and the Bajío seem to have played a preponderant role in these interactions, through mechanisms that have yet to be explored. For example, the discovery of a "barrio michoacano" in Teotihuacan (Gómez Chávez 2002; Gómez Chávez and Gazzola 2007) showed that populations from the West took part in the development of the Classic period metropolis and that products from the metropolis were imported and often imitated in or beyond their regions of origin (Carot 2005; Filini 2004; Hernández 2016; Matos Moctezuma and Kelly 1974; Michelet and Pereira 2009).

After the fall of Teotihuacan, the appearance of new ceramic products in the Basin of Mexico has been interpreted as a marker of migrations from the Bajío, as in the case of the Coyotlatelco complex (Braniff 1972, 1999; Manzanilla 2005) or certain productions from the Early Postclassic (Braniff 1999). During this later period, the emergence and development of the Toltec state marked the establishment of a new system of macro-regional interaction, in which Tula seemed to play a driving role (Diehl 1993). In western Mexico (Jiménez Betts 2018), this trend has been identified in diverse regions based on the presence of material markers, including Mazapa-style figurines, Tlaloc effigy censers, certain forms of incense burners, and the famous Plumbate ware. In southwestern Pátzcuaro Basin, elite burial goods from Urichu include many types of goods known from Tula, such as censers, ceramic vessels, flutes, and projectile point types found at the Palacio Quemado at Tula (Helen Pollard, personal communication 2018). According to the discovery contexts, which are generally ceremonial centers, Plumbate type pottery seems to be reserved for ritual use and linked to the elite. In the words of
R. Cobean (1990:481) "Tal vez eran artículos importantes 'de lujo' usados sobre todo por grupos de élite social para reforzar su alto estatus." ("Perhaps they were important 'luxury' items used mostly by social elite groups to reinforce their high status" [translation by author].)

This article provides new data on the circulation of Plumbate type pottery in the Michoacán highlands, based on the analysis of a recently discovered collection from the site of El Palacio (Zacapu, Michoacán), as part of the Uacúsecha Project. The results of these analyses reveal that in addition to the examples imported from the region of Soconusco by the alleged intermediary of Tula, producers in Michoacán also imitated Plumbate vessels, which they supplied to local elites.

\section{The Long-Distance Diffusion of Plumbate Pottery}

\section{Origins}

Plumbate ware originally came from the Pacific side of the region of Chiapas and Guatemala (Figure 1; Neff 2002a, 2003; Neff and Bishop 1988 ) and was very widely diffused throughout Mesoamerica (Shepard 1948). This production is diagnostic of the Toltec Horizon and is characterized by a very hard coating with a metallic aspect and a color varying from orange to gray or olive green (Fähmel Beyer 1988; Shepard 1948). The first analyses of Plumbate type sherds carried out by Shepard (1948) suggested that the iron- and alumina-based composition of the slip gave it its vitreous aspect. More recent analyses by Glascock and Neff on the material from the region of Soconusco also brought to light enriched concentrations of sodium and potassium, as well as an enrichment in copper and zinc (Neff 2001, 2002a, 2010). Petrographic (Shepard 1948) and chemical analyses (Neff 1984, 2000, 2002b; Neff and Bishop 1988) of the clays distinguished two Plumbate paste groups: San Juan and Tohil. During the Epiclassic period (AD 600-900), simple Plumbate vessels were the dominant serving vessels in Soconusco, and many, mostly of the San Juan paste group, were exported to the highlands of Guatemala and western El Salvador. 


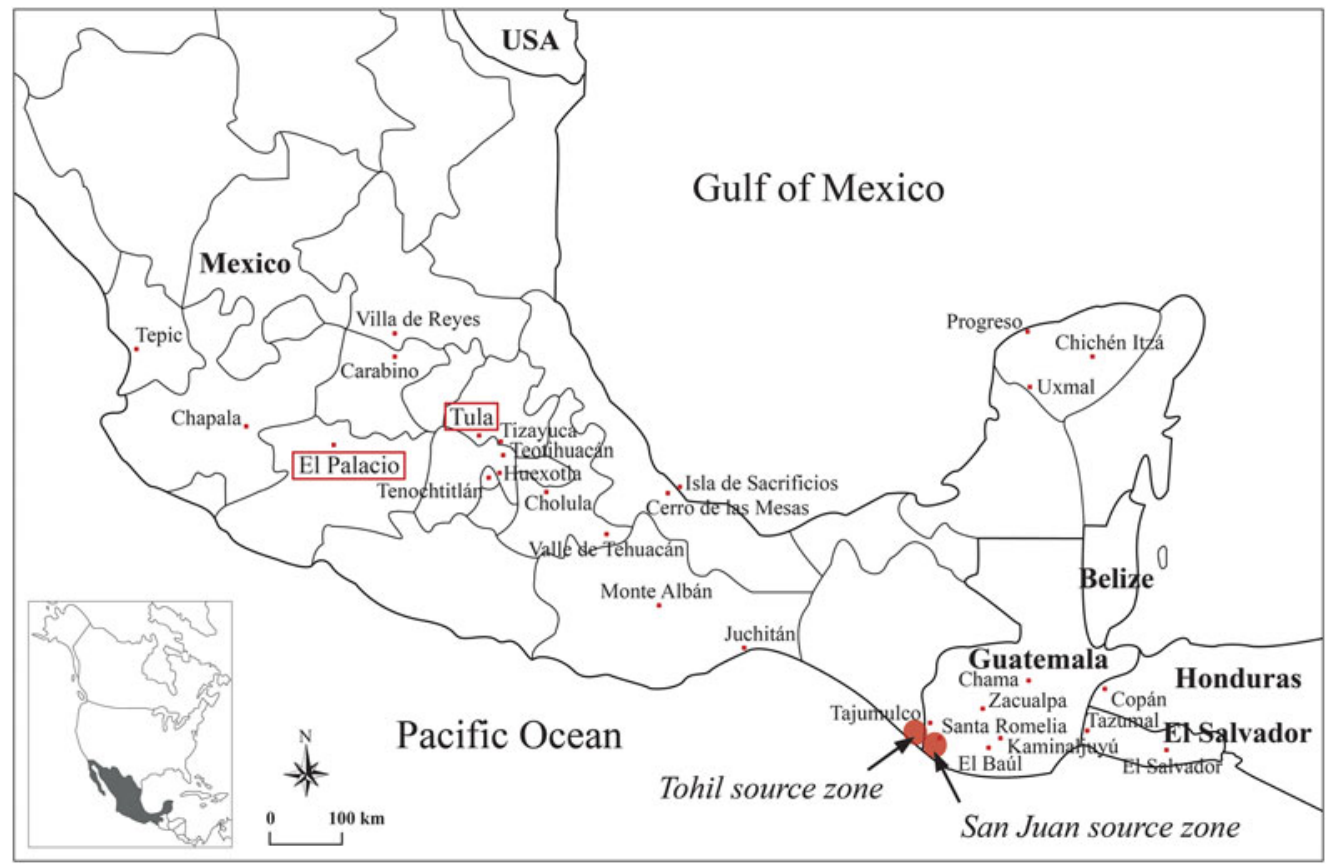

Figure 1. Principal sites with presence of Plumbate pottery in Mesoamerica, with the location of the EI Palacio site, Michoacán, and the two main source zones of Plumbate in the Soconusco region, Chiapas. Map by E. Jadot. (Color online)

During the Early Postclassic (AD 900-1200), fancy vessels made of Tohil clay reached the northern Yucatán peninsula (Chichén Itzá), central Mexico (Tula; Cobean 1990), and western Mexico (Lake Chapala; Meighan 1976; Neff 1989; Shepard 1948). Plumbate production ceased around AD 1100; as of yet, no satisfactory explanation can account for this discontinuation, although the hypothesis of demographic decline in the producing region has been advanced (Neff 2014a).

\section{Diffusion and Imitation}

Plumbate pottery not only links the places of discovery to the region of Soconusco, from where this type originates, but also to other regions of Mexico through which these products may have transited. It is particularly prominent at Tula. According to Diehl (1981:289), "Tohil Plumbate is the most notable ceramic import; over 1,000 sherds and 5 complete vessels were found in the excavations, and 300 sherds were collected during the survey, more than were collected of some of the rare local pottery types. Virtually all the identifiable vessel shapes are drinking goblets." One of the most noteworthy finds was in the main ceremonial center, where a cache of five whole vessels was found in a well located in a structure near an altar ( Figure 2; Diehl et al. 1974).

Shepard (1948) described some imitation Plumbate, but they tend to be easily identified by non-Plumbate features such as polished surfaces or post-slip incising. Although no analyses have been carried out on the material from Tula to confirm that they are Plumbate, they clearly have the vitrified surfaces of true Plumbate, and we are certain that they are not imitations. In contrast, a Plumbate-like effigy vessel discovered in the Templo Mayor at Tenochtitlán was determined by instrumental neutron activation analyses (INAA) to have been produced in the Basin of Mexico (López Luján 2006). Its similarity to other jar effigies from the Early Postclassic period at Teotihuacán suggests that it may have been discovered at the site by the Mexicas and reused as an offering in Tenochtitlán (López Luján 2006), as was also probably the case for the famous 9-Xi vase (López Luján et al. 2000). 


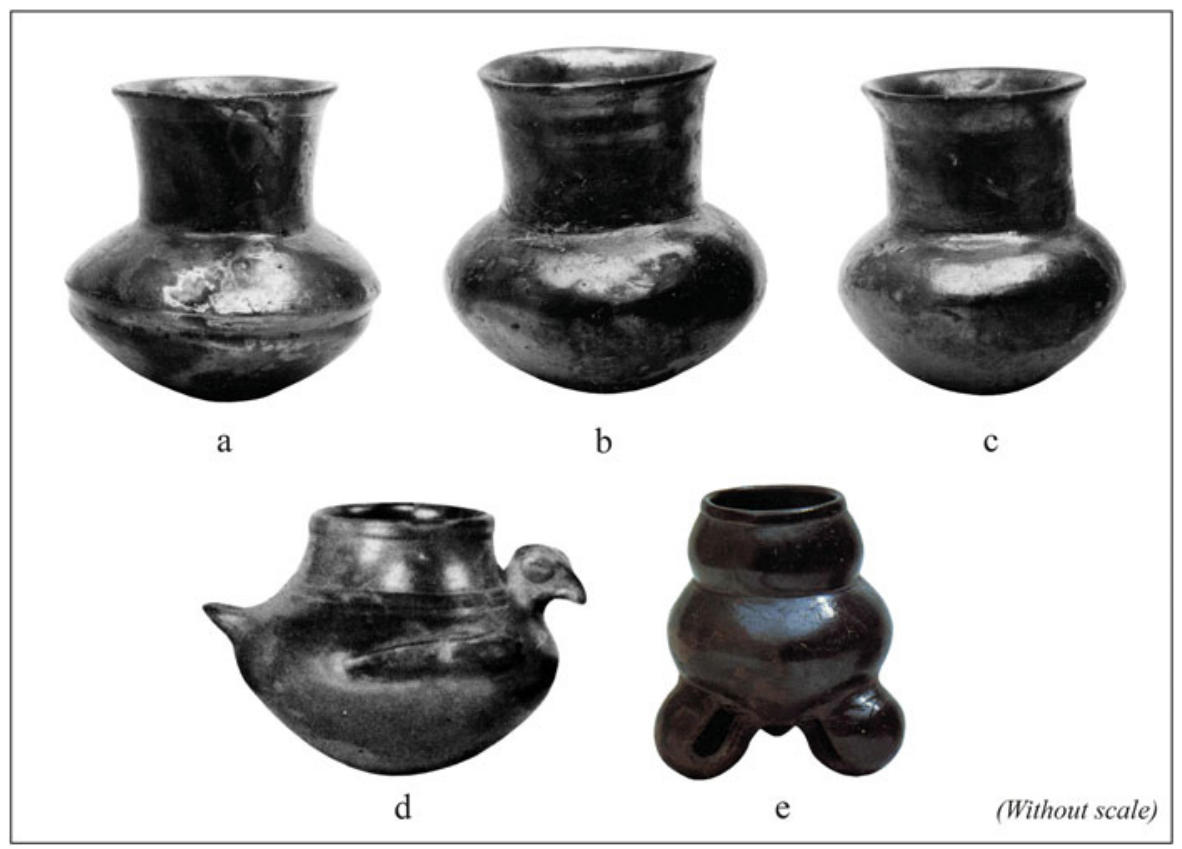

Figure 2. Plumbate type vessels discovered in a cache on the site of Tula (after Diehl et al. 1974:Vessels 5-9). (Color online)

\section{The Site of El Palacio and Its Links with the Toltec Culture}

\section{Context of Discovery}

The site of El Palacio is located in the region of Zacapu, Michoacán (Figure 1), in the southeastern portion of the Malpaís de Zacapu, a vast Holocene volcanic flow from the eruption of the Capaxtiro volcano. The site currently sits above the town of Zacapu and undoubtedly corresponds to the former city of Tzacapo Tacanendan cited in the Relación de Michoacán. It is one of the oldest known establishments in the region and has been studied by several generations of archaeologists (Caso 1930; Freddolino 1973; Lumholtz 1973[1902]). Nevertheless, as part of the Michoacán Project, it underwent more rigorous research from the 1980s onward (Michelet 1992, 1998; Michelet et al. 1989), which outlined its morphological characteristics and defined the occupation chronology. Surveys showed that the site extends across about 50 ha and located some of the ceremonial centers. Test pits indicated that the site was mainly occupied during the Early (Palacio phase: AD 9001200) and Middle Postclassic (Milpillas phase:
AD 1200-1450). Later research carried out in the 1990s by Fernández-Villanueva (1992) focused mainly on the Milpillas phase of occupation. More recently, new research was conducted on El Palacio as part of the Uacúsecha Project, directed by G. Pereira (CNRS/MEAE/ CEMCA), to gain a better understanding of the background of the Tarascan state. New surveys, cartography, and surface collections in 2010 generated a new plan and a more detailed analysis of the spatial organization of the site (Forest 2014). Most of the ceremonial structures have now been located, and a habitation sector corresponding to the Milpillas phase occupation has been systematically mapped. Finally, in 2012, three stratigraphic test pits were excavated in zones where material from the Palacio phase had been found on the surface (Jadot 2013). One of these (UT52) led to the discovery of several layers containing abundant material dated to the Early Postclassic (AD 900-1200). This $2 \times 2 \mathrm{~m}$ test excavation penetrated deposits on one of the ceremonial places of the site, several meters to the west of pyramid Y5 (Figure 3). The Plumbate-like sherds discussed in this article were discovered in these layers. 


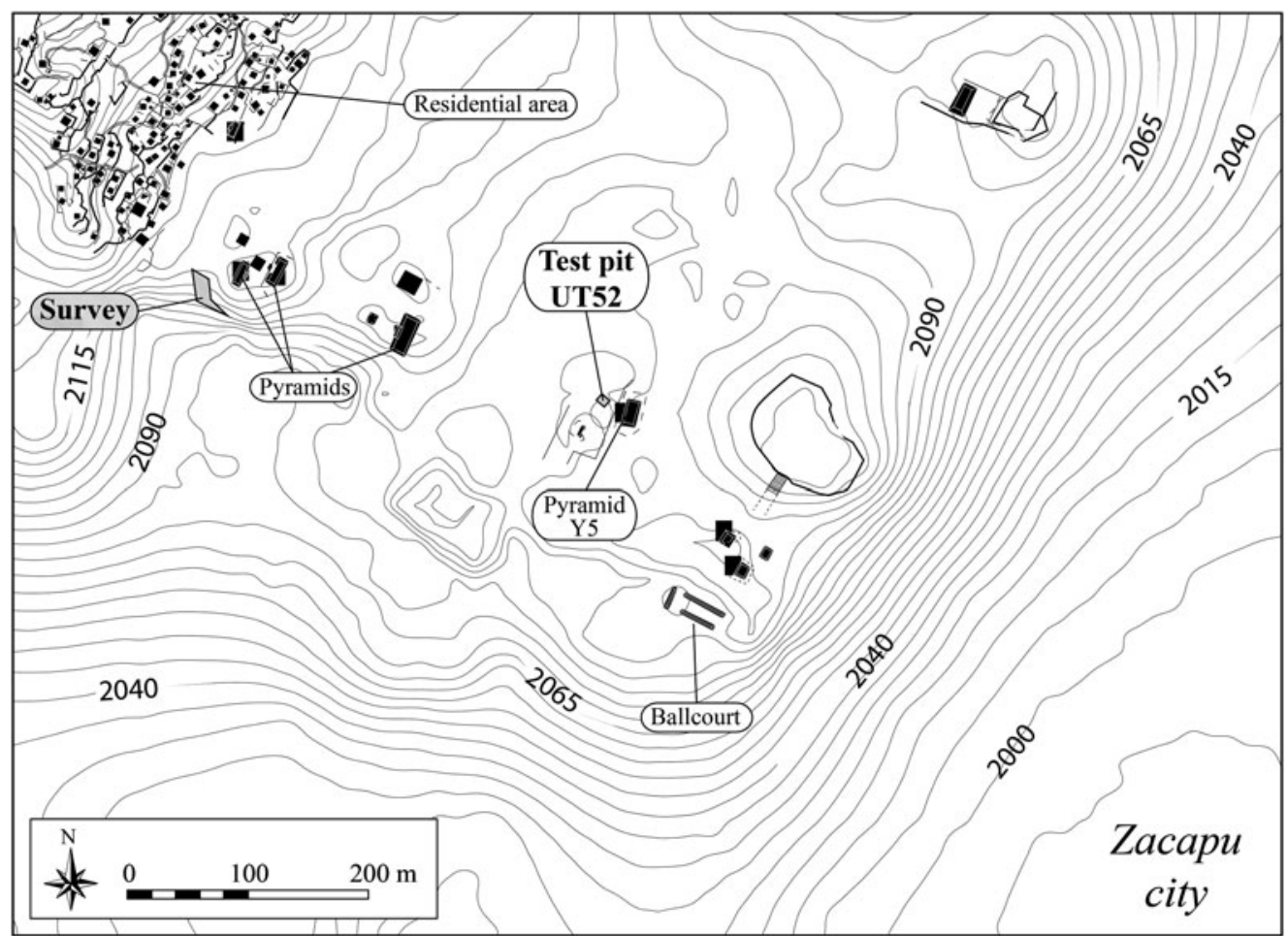

Figure 3. Location of test pit UT52 and the prospected plot at the site of El Palacio, which yielded the analyzed sherds. Map after Forest 2014: Fig.41

The stratigraphic contexts associated with this material were dated by two charcoal samples (from levels UE553 and UE555) and a faunal bone (from level UE554), which provided the following radiocarbon dates (Supplementary Figures 1-3): $953 \pm 12$ BP (GrM11623; charcoal; $\left.\delta^{13} \mathrm{C}=-24.06 \%\right), \quad 1060 \pm 12$ BP (GrM 11625; charcoal; $\left.\delta^{13} \mathrm{C}=-24.25 \%\right)$, and $1055 \pm$ 35 BP (Lyon-11162 [SacA36799]; faunal bone). The calibration of these dates (HPD 95\%: UE555: AD 974-1017; UE554: AD 8961027; UE553: AD 1026-1151) and their stratigraphic position (Figure 4) place the objects in these levels between AD 974 and AD 1151, which is strictly contemporaneous with the apogee of the Toltec culture. Note that the occupation of the site begins at the end of the Epiclassic period (La Joya phase), as revealed at the lower level (UE530) of test pit UT51 that yields an AMS radiocarbon date of $1275 \pm 45$ BP (Lyon-11161 [SacA36798]; faunal bone; Supplementary Figure 4) and AD 659-869 after calibration (HPD 95\%).

\section{Archaeological Links with the Toltec Culture}

Some of the material from test pit UT52 shows distinct links with the Toltec culture from the Tollán phase (ca. AD 950-1150/1200). For example, the fine monochrome pottery of the Palacio Pulido Inciso group (Supplementary Figure $5 \mathrm{a}-\mathrm{b}$ ) presents clear similarities with the Sillon Incised type bowls from Tula in terms of form, finishing, and decoration (see Supplementary Figure 5c; Cobean 1990:375-383). The Braseros San Antonio type fragments (Supplementary Figure 5d-e) found in UT52 also may have links with the Abra Coarse Brown braseros (see Supplementary Figure 5f; Cobean 1990:399-411). In addition, Plumbate type sherds and ceramic fragments of anthropomorphic Mazapa-style figurines (see Diehl 1983:106-110; Stocker 1974) associated with the Toltec culture were among the material from the test pit (Jadot 2016a; Forest et al. 2019). Links between the material culture of north-central Michoacán and the region of Tula had already been pointed out by Michelet 


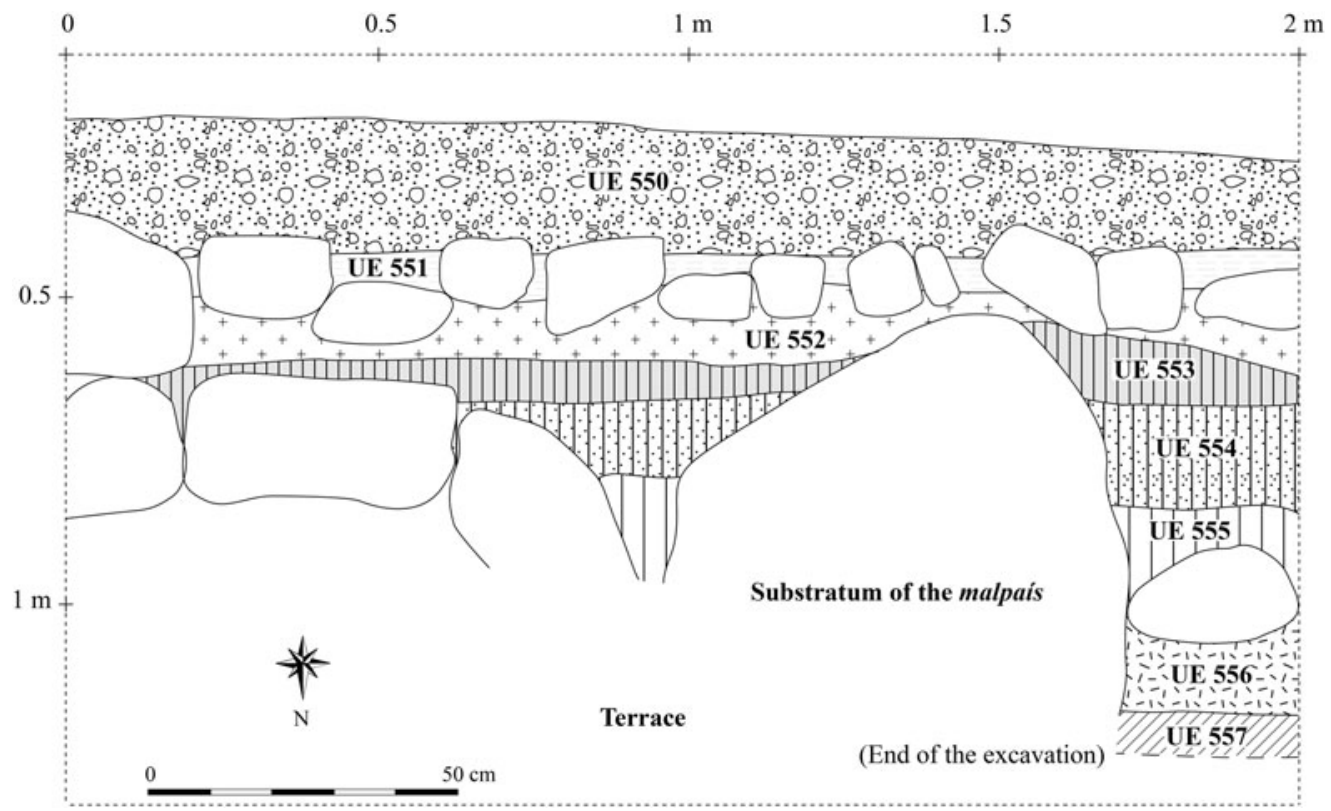

Figure 4. Stratigraphy of test pit UT52 and discovery context of the Plumbate-like sherds. Drawing by E. Jadot.

and Pereira (2000) for the Palacio ceramic complex; in particular, they established strong stylistic similarities (decorative technique and motifs) between the Hornos Rojo sobre Bayo type pottery (Supplementary Figure 5g; Michelet 2013) and the Mazapa Red on Brown type of the terminal Corral phase from Tula (AD 900-950; see Supplementary Figure 5h; Cobean 1990:267-280). Other elements from of the funerary adornments (Pereira 1999) also had similarities to the warrior paraphernalia depicted in Toltec iconography. Nevertheless, the authors concluded, "In contrast with the northwest (the Lake Chapala region) and the northeast (the Ucareo-Zinapecuaro zone), this northern-central part of the modern state does not seem to have received important influences from Tula nor, even less, to have been included within a Toltec political and/or economic sphere" (Michelet and Pereira 2000:6). The recent discoveries at the site of El Palacio enable us to discuss this interpretation.

\section{Plumbate Type Pottery from the Site of El Palacio}

Test pit UT52 at El Palacio (Figures 3 and 4) yielded numerous ceramic fragments comparable to Plumbate ware (Table 1). No Plumbate ceramic artifacts had been recorded in the region of Zacapu before this discovery, apart from two sherds listed in the collections of the American Museum of Natural History in New York City (Ross 1939:Table 1). To our knowledge, no analyses were done on those two sherds.

\section{Technological Characteristics of the Plumbate-Like Pottery}

At the site of El Palacio, Plumbate-like pottery was first identified on the basis of its carefully polished and extremely glossy slip, which had an almost metallic aspect, and the dark gray (Munsell Soil Color Charts: 10YR 2/1-10YR 4/1), reddish-brown (7.5YR 4/2), or red color (10R 3/6). Most of the fragments come from cylindrical forms with a diameter of $3.5-4.6 \mathrm{~cm}$ (Figures 5 and $6 \mathrm{a}-\mathrm{b}$ ); these are interpreted as coming from the long, narrow necks of small bottles that had a shape similar to that of the jars discovered in a cache at Tula (Figure 2). Only a few of the sherds belong to open forms. This pottery is made with particularly fine stretched coils $(1 \mathrm{~cm})$ and is polished with a horizontal movement on the internal face and a vertical movement on the external face, with a tool that leaves fine traces and gives the surface a 
Table 1. Quantities of Plumbate-Like Sherds in Test Pit UT52.

\begin{tabular}{lcc}
\hline Level & Number of Sherds & $\begin{array}{l}\text { Minimum Number of } \\
\text { Individuals (MNI) }\end{array}$ \\
\hline UE550 & 3 & 1 \\
UE551 & 1 & 1 \\
UE552 & 5 & 3 \\
UE553 & 25 & 3 \\
UE554 & 93 & 22 \\
UE555 & 54 & 7 \\
UE556 & 7 & 2 \\
Total & 188 & 39 \\
\hline
\end{tabular}

very high degree of sheen. That the surfaces are polished is indicative that these are not Plumbate, but imitations. We find these finishing characteristics on the same type of pottery discovered in the Templo Mayor at Tenochtitlán, but López Luján (2006) suggests that the latter pottery was made by modeling, without specifying the criteria on which this identification is based. The discoveries made at UT52 include a dark gray specimen with incisions made on the external surface of a wet paste before slipping and a reddish-brown bowl fragment, discovered on the surface of a ceremonial zone of the site during surveys in 2010 (Figures 3 and 5c), with a decoration of appliqué pellet on the external face. In the case of the El Palacio sherds, firing is oxido-reducing with a reducing phase followed by a very short oxidation phase: the core of the paste is dark gray to black and very wide, and the beige-colored edges are very narrow.

Analyses by X-ray fluorescence (XRF), X-ray diffraction (XRD), and Raman spectroscopy were conducted on a sherd from UT52 (CPP437) as part of a more general study of the ceramic pigments used on the Malpaís de Zacapu. The results showed the use of graphite, associated with a carbon deposited by smoking, at the end of the firing process, giving a shiny and metallic aspect to the surface of this sherd (Jadot et al. 2016). The graphite was applied on the surface of the pottery before burnishing, perhaps by rubbing a solid graphite mass (plumbago) on the surface (see Balfet et al. 1992:123).

\section{Paste Groups}

Observed with the naked eye and the stereomicroscope, the Plumbate-like sherds all present a fine paste with a variable quantity of fine black inclusions. Some of these pastes underwent a preliminary petrographic analysis with the help of M.-A. Courty (CNRS, UPR 8521 PROMES), resulting in the identification of three main groups: (1) a silty paste from a volcanic alteration soil, containing a lot of small volcanic glass and carbonaceous fibers, with a temper composed of volcanic breccia (Figure 6a, color online); (2) a sandy paste from an alteration soil, which was decanted and cleared of coarse inclusions, with carbonaceous elements well integrated in the mass and with a temper

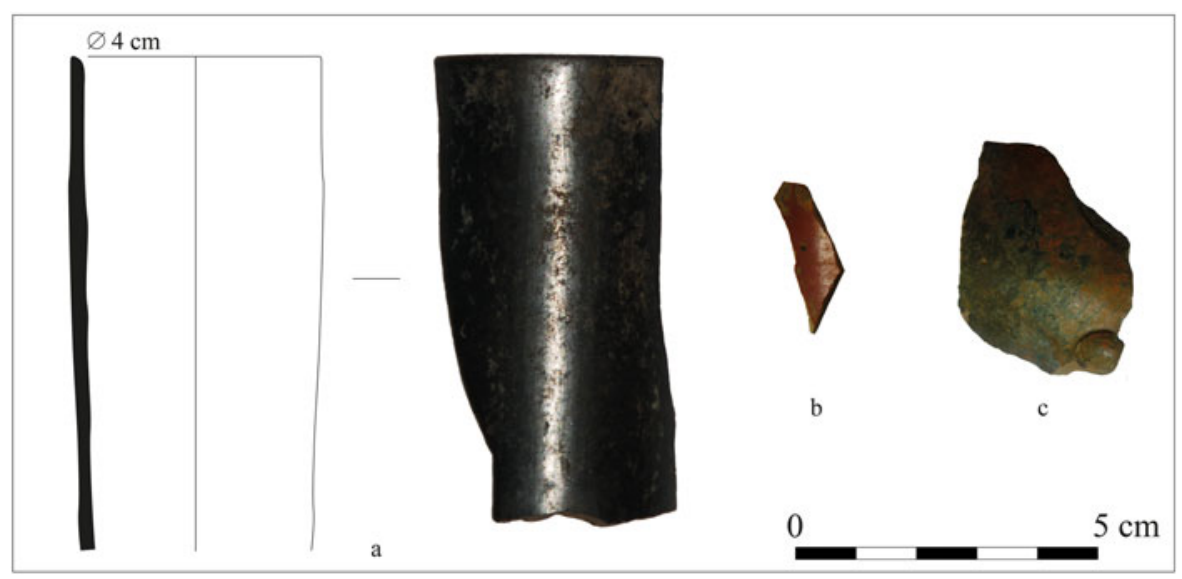

Figure 5. Examples of sherds analyzed for the study at El Palacio, Michoacán: (a-b) test pit UT52, CPP437, and CPP433; (c) survey, CPP435. (Photographs by E. Jadot.) 


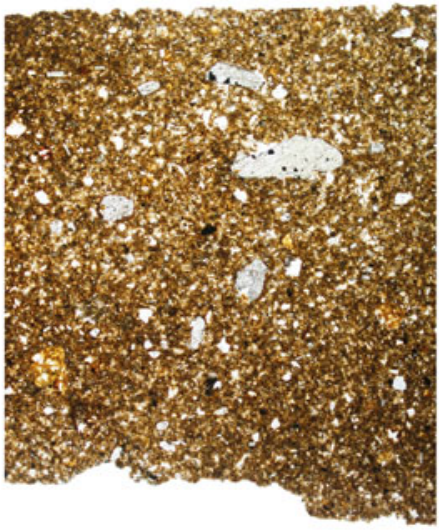

$500 \mu \mathrm{m}$

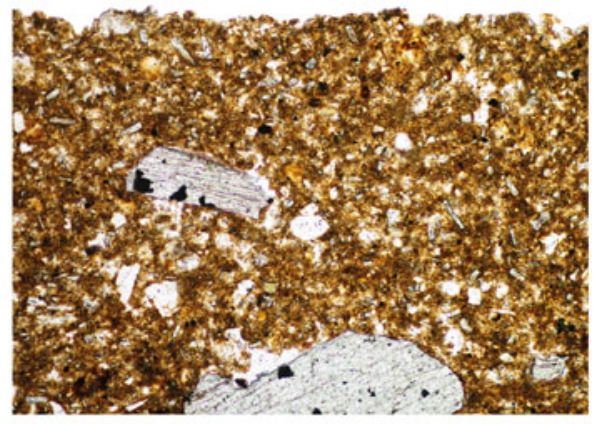

$200 \mu \mathrm{m}$

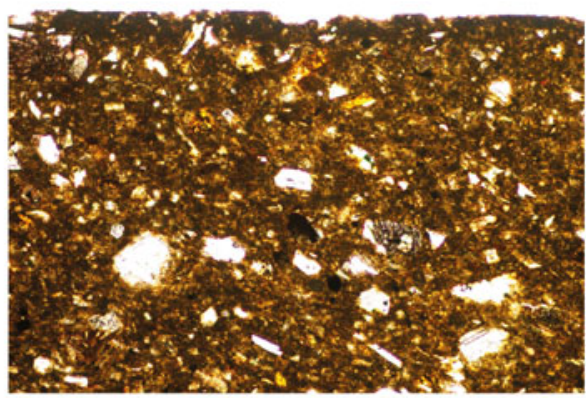

$200 \mu \mathrm{m}$

$1000 \mu \mathrm{m}$

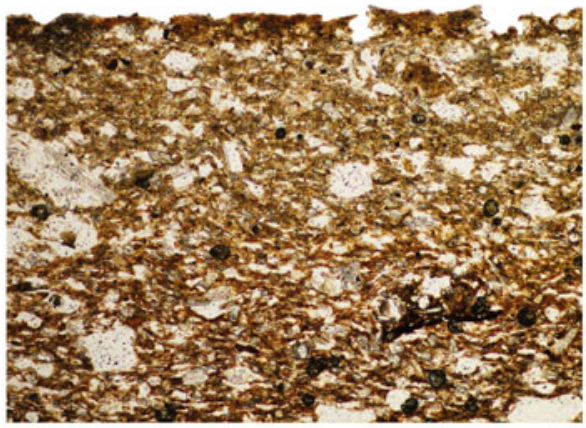

$200 \mu \mathrm{m}$

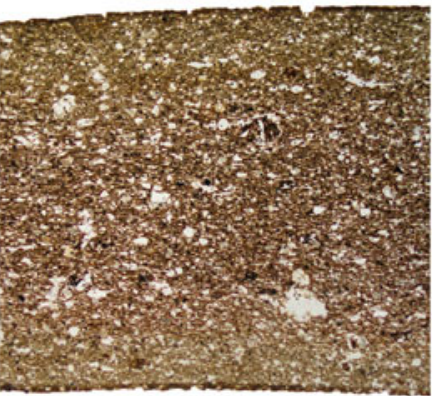

$1000 \mu \mathrm{m}$

Figure 6. Types of pastes: (a) silty, CPP441; (b) sandy, CPP438; (c) clayey-silty-sandy, CPP435. (Photographs by E. Jadot.) 
composed of volcanic breccia (Figure 6b); and (3) a clayey-silty-sandy paste containing altered tephra (Figure 6c). Unfortunately, the thin section corresponding to this third type of paste is too thin to allow adequate observation.

\section{Cultural Implications}

The unprecedented presence of such a quantity of Plumbate type sherds in the region of Zacapu raises questions regarding their provenance. Were these objects imported from a Maya zone, or do they represent a local production of Plumbate copies? To date, Plumbate imitations were easily identifiable as such (Shepard 1948), given that "convincing copies of Plumbate were never produced in the regions to which it was exported. In the case of Plumbate, instead, efforts to produce copies yielded obvious fakes" (Neff 2014b:5). Most of the Plumbate-like sherds from Zacapu have non-Plumbate features, such as polishing, but we decided to select a range of pastes and surface types to undergo instrumental neutron activation analysis (INAA). We expected that the comparison of the chemical composition of the Plumbate ceramic paste from the site of El Palacio and that produced in Soconusco would enable us to define whether these ceramic pastes are from the same source. Overall, the goal of the analysis was to determine to what extent the El Palacio Plumbate-like pottery represents commercial exchange or local imitation.

\section{Results}

We selected sherds with a range of shiny surfaces, including some that were polished and others that were apparently not polished (Table 2). Ten monochrome fragments come from the test pit UT52, whereas one sherd with appliqué decoration was discovered on the surface (Figure 3).

Neff and Glascock at the Missouri Research Reactor Center (MURR) conducted a study of the 11 sherds using INAA (see Neff 2000). They evaluated provenance by comparing the ceramic pastes of Michoacán samples with two Plumbate reference groups and the reference groups available for the Lake Pátzcuaro Basin
Table 2. Provenance and Description of the Analyzed Sherds.

\begin{tabular}{llll}
\hline $\begin{array}{l}\text { Analytical } \\
\text { ID }\end{array}$ & Form & $\begin{array}{l}\text { Surface } \\
\text { Color }\end{array}$ & Origin \\
\hline CPP431 & Miniature jar? & Red & UT52, UE554 \\
CPP432 & Miniature jar? & Brown & UT52, UE555 \\
CPP433 & Miniature jar? & Red & UT52, UE554 \\
CPP434 & Miniature jar? & Brown & UT52, UE553 \\
CPP435 & Bowl? With & Reddish & Surface, \\
& appliqué & gray & parcel 45 \\
& decoration & & south \\
CPP436 & Restricted vessel & Gray & UT52, UE553 \\
CPP437 & Miniature jar? & Gray & UT52, UE555 \\
CPP438 & Restricted vessel & Gray & UT52, UE555 \\
CPP439 & Bowl? & Gray & UT52, UE555 \\
CPP440 & Bowl & Gray & UT52, UE556 \\
CPP441 & Miniature jar? & Gray & UT52, UE554 \\
\hline
\end{tabular}

(Pollard et al. 2005; Speakman 2003) located near Zacapu.

Multivariate probabilities of membership in the reference groups (Table 3) rule out a Soconusco origin for 10 of the 11 sherds from the Zacapu area. The 10 specimens fall within the range of variation of a "general Lake Pátzcuaro Basin" group, and one of them (CPP433) exceeds $1 \%$ probability of membership in the Main Pátzcuaro Basin reference group. Thus, although pottery and raw materials from Zacapu have not been sampled extensively, a local Michoacán source can be inferred for these 10

Table 3. Probabilities of Membership in Various Reference Groups Calculated for 11 "Plumbate" Samples from El Palacio, Michoacán.

\begin{tabular}{|c|c|c|c|c|}
\hline $\begin{array}{l}\text { Analytical } \\
\text { ID }\end{array}$ & $\begin{array}{l}\text { San Juan } \\
\text { Plumbate }\end{array}$ & $\begin{array}{l}\text { Tohil } \\
\text { Plumbate }\end{array}$ & $\begin{array}{l}\text { General } \\
\text { Pátzcuaro } \\
\text { Basin }\end{array}$ & $\begin{array}{l}\text { Main } \\
\text { Pátzcuaro } \\
\text { Basin } \\
\text { Reference } \\
\text { Group }\end{array}$ \\
\hline CPP431 & 0.000 & 0.000 & 4.058 & 0.020 \\
\hline CPP432 & 0.000 & 0.000 & 0.193 & 0.000 \\
\hline CPP433 & 0.000 & 0.000 & 44.071 & 2.425 \\
\hline CPP434 & 0.000 & 0.000 & 5.637 & 0.024 \\
\hline CPP435 & 0.000 & 3.444 & 0.000 & 0.000 \\
\hline CPP436 & 0.000 & 0.000 & 77.208 & 0.819 \\
\hline CPP437 & 0.000 & 0.000 & 4.231 & 0.069 \\
\hline CPP438 & 0.000 & 0.000 & 7.489 & 0.000 \\
\hline CPP439 & 0.000 & 0.000 & 0.918 & 0.106 \\
\hline CPP440 & 0.000 & 0.000 & 72.446 & 0.266 \\
\hline CPP441 & 0.000 & 0.000 & 5.529 & 0.107 \\
\hline
\end{tabular}


specimens. On many bivariate projections of the data (Figure 7, color online), these 10 specimens fall within the range of variation of Pátzcuaro Basin Group 3, which was defined in a followup study of Pátzcuaro Basin pottery by Speakman (2003).

One specimen (CPP435) shows practically no similarity to the Pátzcuaro Basin pottery and raw materials and exceeds the $1 \%$ probability cutoff for membership in the Tohil Plumbate reference group (Table 2). CPP435 is also very different from Pátzcuaro pottery and raw materials on most two-dimensional projections of the data (Figure 7). Because the Tohil Plumbate group is well represented (250+ members) and very tight (Figure 8, color online), this result confirms the identification of CPP435 as an imported Tohil Plumbate vessel. The Tohil Plumbate reference group is securely linked to raw materials near the mouth of Rio Cahuacán, in southern Chiapas, Mexico (Neff 2002a), where Plumbate pottery workshops were recently excavated (Neff 2014b).

These results indicate that one sherd (CPP435) was produced in the Soconusco and then imported to the Zacapu region, whereas the 10 other sherds coincide with the chemical signatures of ceramic pastes produced in the southwestern Pátzcuaro Basin that are most similar to the Pátzcuaro Main Group and Groups 3 and 5 (Hirshman 2003:221, 231; Hirshman and Ferguson 2012; Pollard et al. 2001, 2005). The silty and sandy clays from the alteration soil (Figure 6a-b) were thus extracted in the lowlands of the southwestern Pátzcuaro Basin, about $40 \mathrm{~km}$ from the site of El Palacio. It is likely that the finished products themselves, rather than the raw materials, were transported. These results still have to be compared to the compositions from the region of Zacapu, for which no analyses have yet been conducted. Yet, based on the results presented here, we can envisage the existence of imports from Pátzcuaro Basin to the site of El Palacio during the Early Postclassic (AD 900-1200).

\section{Discussion}

This study indicates that Early Postclassic longdistance exchange networks brought at least some Tohil Plumbate to Michoacán, where local potters also used local technological practices to produce Plumbate-like surfaces. Commercial exchanges have already been identified between Chiapas and the highlands of Michoacán following the discovery of obsidian from a Ucareo source at the site of Izapa, located in the region of Soconusco; in addition, there is evidence of exchanges from central Mexico, such as Pachuca and Otumba, near the region of Tula (Braswell 2003). It is now important to assess whether these exchanges took place directly between the regions of Soconusco and Zacapu or whether the contacts passed through the intermediary of another region, in particular the Basin of Mexico.

Shepard observed that all the original Plumbate type ceramic artifacts are incised before slipping, whereas the imitations are all incised after that process (Shepard 1948), as if there had been no technical transmission between the potters from the region of Soconusco and those trying to copy them. In the case of the specimens from Zacapu, not only did the potters imitating the Plumbate succeed in attaining a high level of shine but they also made incisions before applying the slip. Nevertheless, these features do not enable us to assume that technical transfers took place between the two regions. First, the incision technique before slipping is attested for other productions in the region of Zacapu during the Palacio phase (Palacio Pulido Inciso type bowls; Jadot 2016a, 2016b), and thus it is not a new characteristic exclusively linked to this pottery. Second, there is at least one technique that was not transferred: the technique of dipping in the slip and achieving the shine purely by firing properties of the raw materials. Moreover, the slip "recipe" is different for the pottery produced in Chiapas (with an iron and alumina base, completed by sodium, potassium, copper, and zinc; Neff 2001, 2002a, 2010; Shepard 1948) than for the specimens from Zacapu (use of graphite; Jadot et al. 2016).

Therefore, we argue that there was no transfer of technology from the region of Soconusco to Michoacán: with the exception of the pre-slip incising, the Michoacán "Plumbate" is technologically very different from real Plumbate, the main difference being that graphite and polishing 


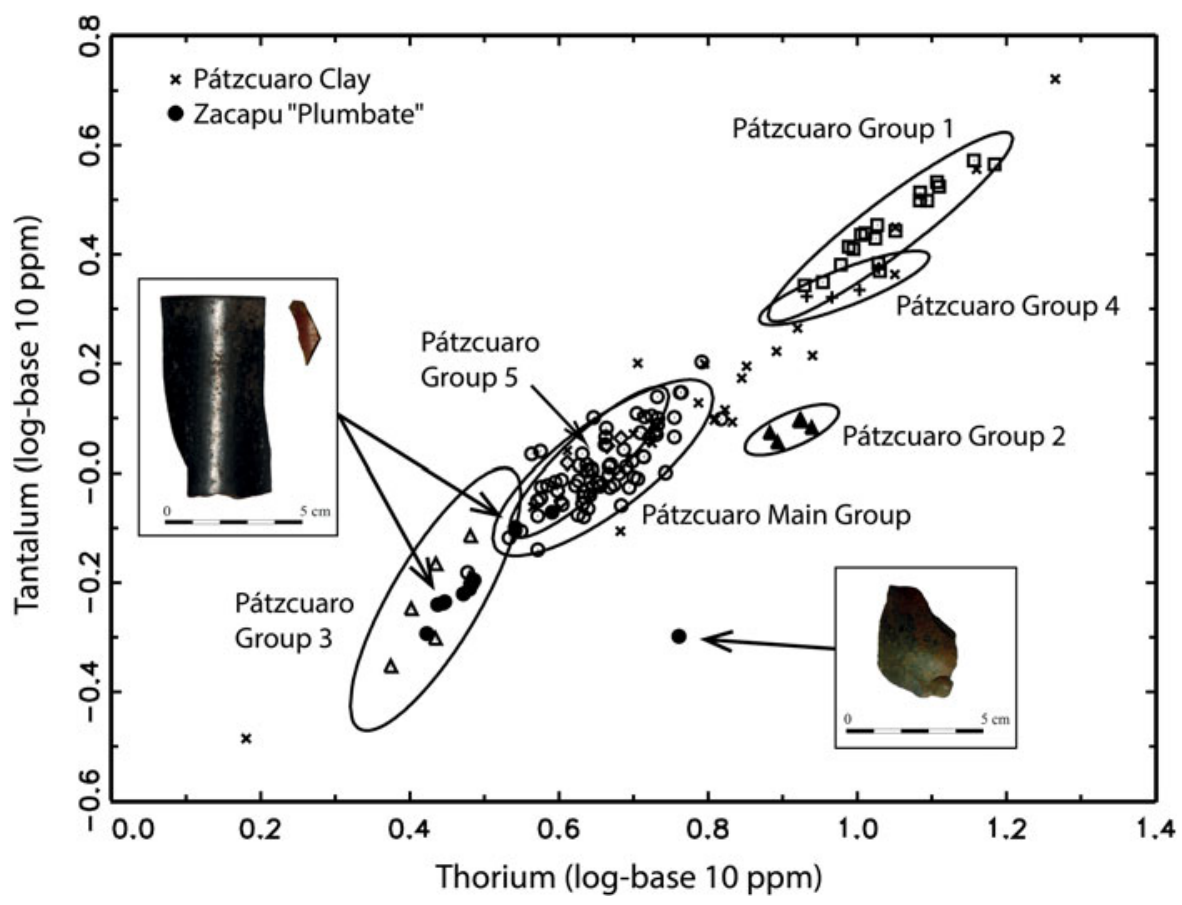

Figure 7. Thorium and Tantalum concentrations in Zacapu "Plumbate" together with ceramics and raw materials from the Lake Pátzcuaro Basin, Michoacán. Ellipses indicate $90 \%$ probability cutoff for membership in the reference groups. The outlier to the right of Michoacán correlation line is CPP435.

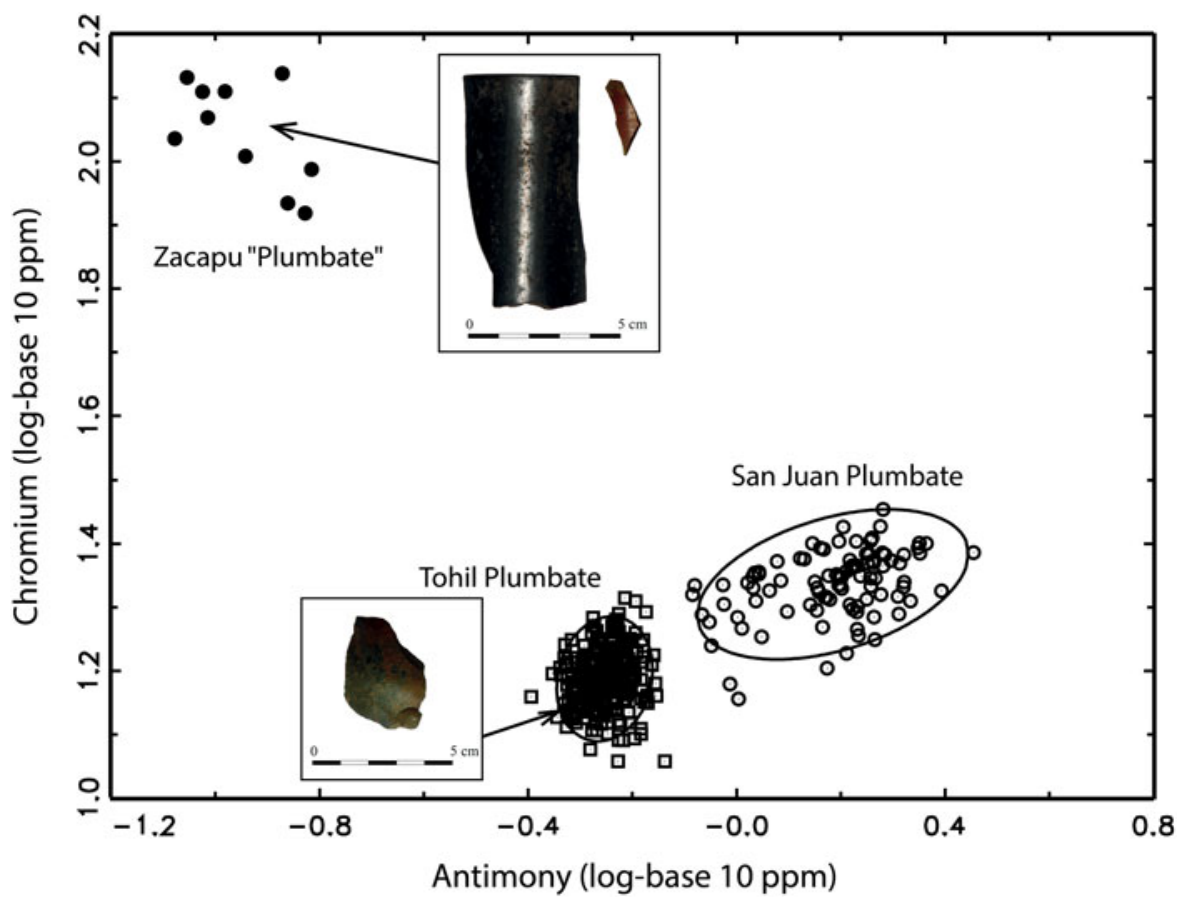

Figure 8. Antimony and chromium concentrations in Zacapu "Plumbate" together with two Plumbate reference groups. Ellipses indicate $90 \%$ probability cutoff for membership in the reference groups. CPP435 is within the cloud of Tohil Plumbate data points, although it is obscured by other data. 
were used in the former to obtain a shiny gray surface; in contrast, Plumbate potters achieved this effect by using special raw materials for the slip and firing in a special atmosphere. Thus the Michoacán "Plumbate" does not represent a genuine reproduction of the whole chaîne opératoire but just the imitation of several characteristics without any understanding of the technology; this imitation could be the result of the attentive observation of the visible traits of finished products issued from commercial exchanges associating the two regions. Contact could have been established in several stages, probably via Toltec populations from the central highlands of Mexico.

We saw earlier that several ceramic indications from the Early Postclassic (AD 9001200) link the site of El Palacio to that of Tula. The discovery of Braseros San Antonio, Palacio Pulido Inciso, Plumbate, and comales type sherds associated with several fragments of Mazapa-style figurines (Forest et al. 2019) indicates contacts with the Toltec culture. The region of Tula could have operated as a transit point for Plumbate between the regions of Soconusco and Zacapu. El Palacio pottery thus reflects exchanges between populations from the regions of Tula and Zacapu during the Early Postclassic. This observation is valid for the site of El Palacio and requires confirmation from other sites in the Zacapu Basin that it is not limited to El Palacio; however, the presence of other objects associated with the Toltec culture at the site of Potrero de Guadalupe (Mich.215), located in the lomas (Pereira 1997), implies that several groups in Zacapu Basin had established links with the Toltecs.

The nature of these links remains to be established. Were they created by commercial networks alone? Or were there more complex and tighter links suggesting forms of alliances between certain elites from Michoacán and Tula? This latter hypothesis was recently put forward by Jiménez Betts (2018) in his analysis of the interactions between the west and the northwest regions of Mesoamerica with central Mexico. The same "Toltec package" is found as far as Jalisco and Nayarit, where Plumbate-style sherds, toltec-type braseros, incensarios, and especially Mazapa figurines are widespread and abundant (Meighan 1976), raising the question of the nature of the Toltec presence in western Mesoamerica. Based on evidence from the sites of Urichu (Pollard 2008; Pollard and Cahue 1999) and El Palacio, Jiménez Betts suggests that the links between the lacustrine zones of Michoacán and Tula are part of a political network system, as defined by Chase-Dunn and Lerro (2014) in their world-system model. Jiménez Betts (2018:63) refers to "zones where sovereign polities have regular political or military exchanges with a core zone. In this case evidence suggestive of political alliances is examined."

We feel it is premature to affirm the existence of direct political links between Tula and the sites considered here. Yet currently available material evidence clearly shows that these populations had sufficient knowledge of the Toltec world to reproduce a wide range of objects for their own use, on a local scale. They not only include table vessels but also objects (braseros, Mazapa figurines, adornments, and corporal insignia) linked to the ceremonial complex, as proposed by Diehl (1993). The original or imitation Plumbate-style pottery described in this article should undoubtedly be placed in this latter category of objects.

Acknowledgments. This study was conducted as part of a doctoral fellowship from the Paris 1 University - PanthéonSorbonne. Analysis of the sherds was made possible by the NSF grant supporting the Archaeometry Laboratory at the University of Missouri Research Reactor (Number 1621158) and the Proyecto Arqueológico Costa del Soconusco (PACS), which was funded by the U.S. National Science Foundation (BCS-1115361). Permission for destructive analysis was provided by the Instituto Nacional de Antropología e Historia (INAH) de México. We also acknowledge the French Ministère de l'Europe et des Affaires Étrangères (MEAE) and the CNRS (UMR 8096 ArchAm) for their funding of the Archaeological Uacúsecha Project, as well as the CEMCA for providing logistical support. We sincerely thank Marie-Agnès Courty for her invaluable assistance in the characterization of the paste groups.

Data Availability Statement. Since 2010, the Uacúsecha Project has been conducting research on the history of the Tarascan state in the region of Zacapu, Michoacán. It is directed by Grégory Pereira and funded by the Commission of Excavations of the French Ministère de l'Europe et des Affaires Étrangères (MEAE), the Centre National de la Recherche Scientifique (CNRS), and the Paris 1 University (Exodes project). It also receives logistical and institutional support from the Centre d'Études Mexicaines et Centre Américaines (CEMCA), the Instituto Nacional de Antropología et Historia 
(INAH), and the Universidad Nacional Autónoma de México (UNAM). All the material mentioned in this article is curated at the CEMCA, in the town of Mexico.

Supplementary material. To view supplementary material for this article, please visit https://doi.org/10.1017/laq. 2019.24.

Supplementary Figure 1. Radiocarbon analysis results for the sample GrM11623 (charcoal; UE553, UT52, El Palacio).

Supplementary Figure 2. Radiocarbon analysis results for the sample Lyon-11162 [SacA36799] (faunal bone; UE554, UT52, El Palacio).

Supplementary Figure 3. Radiocarbon analysis results for the sample GrM 11625 (charcoal; UE555, UT52, El Palacio).

Supplementary Figure 4. Radiocarbon analysis results for the sample Lyon-11161 [SacA36798] (faunal bone; UE530, UT51, El Palacio).

Supplementary Figure 5. Similar pottery types from the El Palacio and Tula sites: (a-b) Palacio Pulido Inciso type, El Palacio, UT52 (drawing by E. Jadot); (c) Sillon Incised type, Tula, Unit 03N7E12D279 (after Cobean 1990:Plate 183); (d) Braseros San Antonio type, El Palacio, UT52 (drawing by E. Jadot); (e) Braseros San Antonio type, El Palacio (after Michelet 2013:Figure 15.2); (f) Abra Coarse Brown type, Tula, 03534020D145 (after Cobean 1990:Plate 192); (g) Hornos Rojo sobre Bayo type, El Palacio, UT52 (drawing by E. Jadot); and (h) Mazapa Red on Brown type, Tula, 070204130 (after Cobean 1990:Plate 132).

\section{References Cited}

Balfet, Hélène, Marie-France Fauvet-Berthelot, and Susana Monzon

1992 Normas para la descripción de vasijas cerámicas. CEMCA, Mexico.

Braniff C., Beatríz

1972 Secuencias arqueológicas en Guanajuato y la Cuenca de México. Intento de correlación. In Teotihuacán, XI ${ }^{a}$ Mesa redonda, Vol. 2, pp. 273-323. Sociedad Mexicana de Antropología, Mexico City.

1999 Morales, Guanajuato y la tradición tolteca. Colección científica, Serie Arqueología 395. Instituto Nacional de Antropología e Historia (INAH), Mexico City.

Braswell, Geoffrey E.

2003 Obsidian Exchange Sphere. In The Postclassic Mesoamerican World, edited by Michael E. Smith and Frances F. Berdan, pp. 131-158. University of Utah Press, Salt Lake City.

Carot, Patricia

1992 La cerámica protoclásica del sitio de Loma Alta, municipio de Zacapu, Michoacán: nuevos datos. In Origen y desarrollo de la civilización en el Occidente de México, edited by Brigitte Boehm de Lameiras and Phil C. Weigand, pp. 69-101. El Colegio de Michoacán, Zamora.

2005 Reacomodos demográficos del Clásico al Posclásico en Michoacán: el retorno de los que se fueron. In Reacomodos demográficos del Clásico al Posclásico en el centro de México, edited by Linda Manzanilla, pp. 103-122. Universidad Nacional Autónoma de México (UNAM), Mexico City.
Caso, Alfonso

1930 Informe preliminar de las exploraciones realizadas en Michoacán. Anales del Museo Nacional de Arqueología, Historia y Etnología, 4a época 6:446-452. INAH, Mexico.

Chase-Dunn, Christopher, and Bruce Lerro

2014 Social Change: Globalization from the Stone Age to the Present. Paradigm, Boulder, Colorado.

Cobean, Robert $\mathrm{H}$.

1990 La cerámica de Tula, Hidalgo. Colección científica, Estudios sobre Tula 2, Serie Arqueología 215. INAH, Mexico.

Darras, Véronique

2006 Las relaciones entre Chupícuaro y el Centro de México durante el Preclásico reciente. Una crítica de las interpretaciones arqueológicas. Journal de la Société des Américanistes 92:69-110.

Diehl, Richard A.

1981 Tula. In Handbook of Middle American Indians, edited by Jeremy A. Sabloff, Vol. 1 suppl., pp. 277-295. University of Texas Press, Austin.

1983 Tula, the Toltec Capital of Ancient Mexico. New Aspects of Antiquity. Thames and Hudson, London.

1993 The Toltec Horizon in Mesoamerica: New Perspectives on an Old Issue. In Latin American Horizons: A Symposium at Dumbarton Oaks, 11th and 12th October 1986, edited by Don S. Rice, pp. 263-294. Dumbarton Oaks Research Library and Collection, Washington, DC.

Diehl, Richard A., Roger Lomas, and Jack T. Wynn

1974 Toltec Trade with Central America: New Light and Evidence. Archaeology 27(3):182-187.

Fähmel Beyer, Bernd

1988 Mesoamérica tolteca, sus cerámicas de comercio principales. Serie Antropológicas 95. UNAM, Mexico City.

Fernández-Villanueva, Eugenia

1992 Arqueología de la ciénega de Zacapu. In Anales del Museo Michoacano, Tercera época, Suppl. 4, pp. 11-34. INAH, Morelia.

Filini, Agapi

2004 The Presence of Teotihuacan in the Cuitzeo Basin, Michoacan, Mexico: A World-System Perspective. BAR International Series 1279. Archaeopress, Oxford.

Filini, Agapi, and Efraín Cárdenas García

2007 El Bajío, la Cuenca de Cuitzeo y el Estado teotihuacano. Un estudio de relaciones y antagonismos. In Dinámicas culturales entre el Occidente, el Centro-Norte y la cuenca de México del Preclásico al Epiclásico: trabajos recientes, edited by Brigitte Faugère, pp. 137-154. Colección Investigaciones. CEMCA / El Colegio de Michoacán, Mexico.

Forest, Marion

2014 L'organisation sociospatiale des agglomérations urbaines du Malpaís de Zacapu, Michoacán, Mexique [1250-1450 après J.-C.]. PhD dissertation, Department of History of Art and Archaeology, University of Paris 1.

Forest, Marion, Elsa Jadot, and Juliette Testard

2019 Mazapan-Style Figurines at El Palacio: What Significance for the Early Postclassic Interregional Interactions in Northern Michoacán? Ancient Mesoamerica, in press.

Freddolino, Mary Kimball

1973 An Investigation into the "Pre-Tarascan" Cultures of Zacapu, Michoacán, México. PhD dissertation, Department of Anthropology, Yale University, New Haven, Connecticut. University Microfilms, Ann Arbor. 
Gómez Chávez, Sergio

2002 Presencia del occidente de México en Teotihuacán. Aproximaciones a la política exterior del Estado teotihuacano. In Ideología y Política a través de materiales y símbolos. Memorias de la Primera Mesa Redonda de Teotihuacan, edited by María Elena Ruiz-Gallut, pp. 563-625. INAH / UNAM, Mexico City.

Gómez Chávez, Sergio, and Julie Gazzola

2007 Análisis de las relaciones entre Teotihuacán y el Occidente de México. In Dinámicas culturales entre el Occidente, el Centro-Norte y la cuenca de México del Preclásico al Epiclásico: trabajos recientes, edited by Brigitte Faugère, pp. 113-135. Colección Investigaciones. CEMCA / El Colegio de Michoacán, Mexico.

Hernández, Christine L.

2016 Ceramic Evidence of Teotihuacan Contact Linking the Basin of Mexico, the Bajío, and Southern Hidalgo. In Cultural Dynamics and Production Activities in Ancient Western Mexico, edited by Eduardo Williams and Blanca Maldonado, pp. 215-238. Archaeopress Archaeology, Oxford.

Hers, Marie-Areti

2005 Imágenes norteñas de los guerreros toltecaschichimecas. In Reacomodos demográficos del Clásico al Posclásico en el centro de México, edited by Linda Manzanilla, pp. 11-44. UNAM-IIA, México City. Hirshman, Amy J.

2003 A Case Study in the Relationship between Social Complexity and the Organization of Ceramic Production from the Lake Pátzcuaro Basin, Michoacán, Mexico. $\mathrm{PhD}$ dissertation, Department of Anthropology, Michigan State University, East Lansing.

Hirshman, Amy J., and Jeffrey R. Ferguson

2012 Temper Mixture Models and Assessing Ceramic Complexity in the Emerging Tarascan State. Journal of Archaeological Science 39:3195-3207.

Jadot, Elsa

2013 Sondeos estratigráficos en el sitio de El Palacio (Mich.23). In Informe técnico sobre los trabajos de campo llevados a cabo en Malpaís Prieto y otros asentamientos de la región de Zacapu, Michoacán. Temporada 5 (2012), edited by Grégory Pereira, pp. 107-124. Manuscript on file, Consejo de Arqueología, INAH, Mexico City.

2016a Productions céramiques et mobilités dans la région tarasque de Zacapu (Michoacán, Mexique) Continuités et ruptures techniques entre 850 et 1450 apr. J.-C. PhD dissertation, Department of History of Art and Archaeology, University of Paris 1.

2016b Technologie céramique et «frontières culturelles ». L'exemple des techniques de décors céramiques de deux sites postclassiques du Malpaís de Zacapu (Mexique) : Palacio et Malpaís Prieto. Archeo.Doct 9. Presses de la Sorbonne, Paris. Electronic document, https://books. openedition.org/psorbonne/6385, accessed June 6, 2018.

Jadot, Elsa, Nick Schiavon, and Marta Manso

2016 The Ceramics of Malpaís of Zacapu, Michoacán, Mexico, during the Early and Middle Postclassic Periods (900-1450 AD): Micro-Chemical Characterization of Surface Paintings. Spectrochimica Acta Part B: Atomic Spectroscopy 119:10-16.

Jiménez Betts, Peter

1992 Una red de interacción del noroeste de Mesoamérica: una interpretación. In Origen y desarrollo de la civilización en el occidente de México: homenaje a
Pedro Armillas y Ángel Palerm, edited by Brigitte Boehm de Lameiras and Phil C. Weigand, pp. 177204. El Colegio de Michoacán, Zamora.

2018 Orienting West Mexico: The Mesoamerican World System 200-1200 CE. PhD dissertation, Faculty of Arts, University of Gothenburg, Sweden.

López Luján, Leonardo

2006 La casa de las águilas I, Un ejemplo de la arquitectura religiosa de Tenochtitlán. INAH / CONACULTA, Mexico City.

López Luján, Leonardo, Hector Neff, and Saburo Sugiyama 2000 The 9-Xi Vase: A Classic Thin Orange Vessel Found at Tenochtitlan. In Mesoamerica's Classic Heritage: From Teotihuacan to the Aztecs, edited by David Carrasco, Lindsay Jones, and Scott Sessions, pp. 219-249. University Press of Colorado, Boulder.

Lumholtz, Carl

1973 [1902] Unknown Mexico. A Record of five Years Exploration among the Tribes of the Western Sierra Madre, in the Tierra Caliente of Tepic and Jalisco, and among the Tarascos of Michoacan. 2 vols. AMS Press, New York. Originally published 1902, Charles Scribner's Son, New York.

Manzanilla, Linda

2005 Migrantes epiclásicos en Teotihuacán. Propuesta metodológica para el análisis de migraciones del Clásico al Posclásico. In Reacomodos demográficos del Clásico al Posclásico en el centro de México, edited by Linda Manzanilla, pp. 261-273. UNAM-IIA, México City.

Matos Moctezuma, Eduardo, and Isabel Kelly

1974 Una vasija que sugiere relaciones entre Teotihuacan y Colima. In The Archaeology of West Mexico, edited by Betty Bell, pp. 202-205. West Mexican Society for Advanced Study, Ajijic.

Meighan, Clement W.

1976 The Archaeology of Amapa, Nayarit. Archaeologica Monumenta. Institute of Archaeology, University of California, Los Angeles.

Michelet, Dominique

1992 El Centro-Norte de Michoacán: características generales de su estudio arqueológico regional. In $E l$ Proyecto Michoacán 1983-1987. Medio ambiente e introducción a los trabajos arqueológicos, edited by Dominique Michelet, pp. 9-52. Collection Études Mésoaméricaines II-11, Cuadernos de estudios Michoacanos 4. CEMCA, Mexico City.

1998 Topografía y prospección sistemática de los grandes asentamientos del Malpaís de Zacapu: claves para un acercamiento a las realidades sociopolíticas. In Génesis, culturas y espacios en Michoacán, edited by Véronique Darras, pp. 47-59. CEMCA, Mexico City.

2013 Cerámicas del Centro-Norte de Michoacán entre el Clásico y el Posclásico. In Tradiciones cerámicas del Epiclásico en el Bajío y regiones aledañas: cronología $e$ interacción, edited by Chloé Pomédio, Grégory Pereira, and Eugenia Fernández-Villanueva, pp. 91-103. BAR International Series 2519. Paris Monographs in American Archaeology 31, Archaeopress, Oxford.

Michelet, Dominique, and Grégory Pereira

2000 The Classic-Postclassic Transition in North-Central Michoacán: A Debate Case of Toltecization. Paper presented at the 65th Annual Meeting of the Society for American Archaeology, Philadelphia, Pennsylvania.

2009 Teotihuacán y el Occidente de México. In Teotihuacán, Ciudad de los dioses, edited by Felipe R. Solís 
Olguín, Martirene Alcántara, and Gilda Castillo, pp. 79 83. INAH, Mexico.

Michelet, Dominique, Marie-Charlotte Arnauld, and Marie-France Fauvet-Berthelot

1989 El proyecto del CEMCA en Michoacán. Etapa I: un balance. TRACE 16:70-87.

Neff, Hector

1984 The Developmental History of the Plumbate Pottery Industry in the Eastern Soconusco Region, A.D. 600 through A.D. 1250. PhD dissertation, Department of Anthropology, University of California, Santa Barbara.

1989 The Effect of Interregional Distribution on Plumbate Pottery Production. In Ancient Trade and Tribute: Economies of the Soconusco Region of Mesoamerica, edited by Barbara Voorhies, pp. 249-267. University of Utah Press, Provo.

2000 Neutron Activation Analysis for Provenance Determination in Archaeology. In Modern Analytical Methods in Art and Archaeology, edited by Enrico Ciliberto and Giuseppe Spoto, pp. 81-134. John Wiley, New York.

2001 Production and Distribution of Plumbate Pottery: Evidence from a Provenance Study of the Paste and Slip Clay Used in a Famous Mesoamerican Tradeware. Electronic document, http://www.famsi.org/reports/ 98061/98061Neff01.pdf, accessed June 6, 2018.

2002a Sources of Raw Material Used in Plumbate Pottery. In Incidents of Archaeology in Central America and Yucatán, Essays in Honor of Edwin M. Shook, edited by Michael Love, Marion Popenoe de Hatch, and Héctor L. Escobedo, pp. 217-231. University Press of America, Lanham, Maryland.

2002b Nuevos hallazgos relacionados con la producción de la vajilla plomiza. In $X V$ Simposio de Investigaciones Arqueológicas en Guatemala, 2001, edited by Juan Pedro Laporte, Héctor L. Escobedo, and Bárbara Arroyo, pp. 458-469. Museo Nacional de Arqueología y Etnología, Guatemala City.

2003 Analysis of Plumbate Pottery Surfaces by Laser Ablation-Inductively Coupled Plasma-Mass Spectrometry (LA-ICP-MS). Journal of Archaeological Science 30:21-35.

2010 Plumbate Technology Revisited. In Second LatinAmerican Symposium on Physical and Chemical Methods in Archaeology, Art and Cultural Heritage Conservation, edited by José Luis Ruvalcaba Sil, Javier Reyes Trujeque, Jesús Arenas Alatorre, and Adrián Velázquez Castro, pp. 140-145. UNAM / INAH / Universidad Autónoma de Campeche, Mexico.

2014a Pots as Signals: Explaining the Enigma of LongDistance Ceramic Exchange. In Craft and Science: International Perspectives on Archaeological Ceramics, edited by Marcos Martinón-Torres. Bloomsbury Qatar Foundation, Doha, Qatar. UCL Qatar Series in Archaeology and Cultural Heritage 1. doi:10.5339/uclq.2014.cas.ch1.

2014b Proyecto Arqueológico Costa del Soconusco (PACS): Informe de la Segunda Temporada de Campo y Solicitud de Permiso para para Julio 2014 hasta Junio 2015. Presented to the Consejo de Arqueología Instituto Nacional de Antropología, Mexico.

Neff, Hector, and Ronald L. Bishop

1988 Plumbate Origins and Development. American Antiquity 53:505-522.

Pereira, Grégory

1997 Costumbres funerarias y sociedad del Clásico tardío en la cuenca de Zacapu, Michoacán. Arqueología 18:61-84.

1999 Potrero de Guadalupe: anthropologie funéraire d'une communauté pré-tarasque du nord du Michoacán, Mexique. BAR International Series 816, Paris Monographs in American Archaeology 5. Archaeopress, Oxford.

Pollard, Helen Perlstein

2008 A Model for the Emergence of the Tarascan State. Ancient Mesoamerica 19:217-230.

Pollard, Helen Perlstein, and Laura Cahue

1999 Mortuary Patterns of Regional Elites in the Lake Patzcuaro Basin of Western Mexico. Latin American Antiquity 10:259-280.

Pollard, Helen Perlstein, Amy Hirshman, Hector Neff, and Michael D. Glascock

2001 Las elites, el intercambio de bienes y el surgimiento del área nuclear tarasca: análisis de la cerámica de la cuenca de Pátzcuaro. In Estudios cerámicos en el occidente y norte de México, edited by Eduardo Williams and Phil C. Weigand, pp. 289-309. El Colegio de Michoacán, Zamora.

2005 Exchange, Elites, and the Emergence of the Tarascan Core. In Archaeology without Limits: Papers in Honor of Clement W. Meighan, edited by Brian D. Dillon and Matthew T. Boxt, pp. 295-307. Labyrinthos, Lancaster, California.

Ross, Virginia L.

1939 Some Pottery: Types of the Highlands of Western Mexico. PhD dissertation, Department of Anthropology, Yale University, New Haven.

Shepard, Anna O.

1948 Plumbate, a Mesoamerican Trade Ware. Publication 573. Carnegie Institution of Washington, Washington, DC.

Speakman, Robert J.

2003 Letter Report to Helen Pollard and Amy Hirshman, December 19, 2003. Manuscript on file at MURR, University of Missouri, Columbia.

Stocker, Terrance L.

1974 Mazapan Figurines from Tula. In Studies of Ancient Tollan: A Report of the University of Missouri Tula Archaeological Project, edited by Richard A. Diehl, pp. 42-55. University of Missouri Monographs in Anthropology 1. University of Missouri, Columbia.

Submitted August 7, 2018; Revised December 4, 2018; Accepted March 12, 2019 